\title{
FURTHER OBSERVATIONS ON THE INFLUENCE OF THE SOCIAL ENVIRONMENT ON OVULATION IN THE VOLE, MICROTUS AGRESTIS
}

\author{
S. R. MILLIGAN \\ Department of Agricultural Science, University of Oxford, Parks Road, Oxford
}

(Received 29th November 1974)

Although members of the species Microtus agrestis are induced ovulators (Austin, 1957; Breed, 1967), ovulation may be induced by stimuli other than those associated with mating, e.g. when females are separated from adult males by wire mesh (Milligan, 1974). Tactile contact between the sexes is not necessary for this ovulatory response as ovulation still occurred when two barriers of mesh, $2.5 \mathrm{~cm}$ apart, separated the male and female (Milligan, 1974). The present experiments continued the investigation of the nature of the effective stimuli for ovulation which are provided by non-coital contact with a male.

Laboratory bred voles from the 'mixed-type' colony described by Milligan (1974) were used. Males were fertile adults from the breeding colony; all females had shown cornified vaginal smears on 3 consecutive days before the experiments. In Exp. 1, virgin females were treated as shown in Table 1. The females were housed individually on a wire-mesh floor supported $5 \mathrm{~cm}$ above the normal solid floor of a wire-topped plastic cage $(29 \times 19 \times 10 \mathrm{~cm})$. A plastic box $(17.5 \times 11.5 \times 6.0 \mathrm{~cm})$, open at the bottom, was placed on the wire floor; this box contained a male in Exps 1B and 1C. Faeces and urine from males and females passed through the mesh of the floor and thus the females in Exps IB and 1C were exposed to male odours. The sides of the box used in Exp. 1C were opaque, preventing visual contact with the male. As a control for this treatment, the sides of the box in Exp. 1A were also opaque. The cages were cleaned, and the males replaced by fresh males, every 3 days.

In Exp. 2, mature virgin females were individually housed in small plastic boxes $(17.5 \times 11.5 \times 6.0 \mathrm{~cm})$ which were clean (Exp. 2A) or had been soiled by a male (Exp. 2B). Each box contained non-absorbent cotton wool as bedding and absorbent tissue as floor covering; perforation of the lid of each box allowed ventilation. The females in Exp. 2A were transferred to clean boxes every $12 \mathrm{hr}$. In Exp. 2B, the males were transferred to clean boxes every $12 \mathrm{hr}$ and the females moved to the freshly vacated boxes. Males were replaced by new males every 3 days.

Vaginal smears were taken daily using a platinum wire loop (neither this technique nor more vigorous mechanical stimulation of the vagina and cervix is able to induce ovulation in M. agrestis: Milligan, 1974, 1975). Females were killed (1) after an interruption of the typical pattern of consecutive cornified vaginal smears by thin or leucocytic smears, which suggested that ovulation might have occurred (Milligan, 1974), or (2) at the end of the 15-day experi- 
Table 1. The effect of social environment on ovulation in voles

\begin{tabular}{|c|c|c|c|c|c|c|}
\hline & \multicolumn{4}{|c|}{ Contact with male } & \multirow{2}{*}{$\begin{array}{l}\text { No. } \\
\text { of } \\
\text { voles }\end{array}$} & \multirow{2}{*}{$\begin{array}{l}\text { No. of } \\
\text { voles } \\
\text { with } C L^{*}\end{array}$} \\
\hline & Tactile & Visual & Auditory & Olfactory & & \\
\hline $\begin{array}{l}\text { Experiment } 1 \\
\text { A. No male } \\
\text { B. Male } \\
\text { C. Male }\end{array}$ & $\begin{array}{l}\overline{\text { No }} \\
\text { No }\end{array}$ & $\begin{array}{l}\overline{\text { Yes }} \\
\text { No }\end{array}$ & $\begin{array}{l}\overline{\text { Yes }} \\
\text { Yes }\end{array}$ & $\begin{array}{l}\overline{\text { Yes }} \\
\text { Yes }\end{array}$ & $\begin{array}{l}15 \\
15 \\
15\end{array}$ & $\begin{array}{l}0 \\
1 \\
2\end{array}$ \\
\hline $\begin{array}{l}\text { Experiment } 2 \\
\text { A. No male } \\
\text { B. Male }\end{array}$ & $\overline{\text { No }}$ & $\overline{\text { No }}$ & $\overline{\text { No }}$ & $\overline{\text { Yest }}$ & $\begin{array}{l}13 \\
13\end{array}$ & $\begin{array}{l}0 \\
1\end{array}$ \\
\hline
\end{tabular}

mental period. The ovaries of each female were examined histologically for evidence of ovulation.

The results (Table 1), together with those previously reported (Milligan, 1974), indicate that ovulation in $M$. agrestis only occurs when the females are exposed to some form of stimulation from males. The results of Exp. $1 \mathrm{G}$ indicate that some females will ovulate even when prevented from both seeing and touching a male. The fact that one female ovulated when exposed to the boxes soiled by males (Exp. 2B) suggests that male pheromones may be involved in mediating the ovulatory response. In all situations in which female voles have been exposed to rather indirect contact with a male (either through a double barrier of wire mesh (Milligan, 1974) or as in Exps 1B, 1C and 2B of the present study), the proportion of females ovulating has been lower than when contact was through only a single barrier of wire mesh (Milligan, 1974). This suggests that, unlike the case for some other social reproductive phenomena in rodents (e.g. the 'Whitten' and 'Bruce' effects in mice: see Bruce, 1970), air-bound olfactory stimuli alone may be relatively ineffective in mediating the induction of ovulation. Pheromones dependent on tactile contact have been implicated in the stimulation of oestrus in the cuis, Galea musteloides, by the presence of the male (Weir, 1973), and it is possible that a similar type of pheromone in voles may be involved in the non-coital induction of ovulation by the presence of a male.

I am especially grateful to Dr J. R. Clarke for his invaluable encouragement and supervision of this work; to Professor J. H. Burnett for providing facilities, and to Miss Judith Tompkins for maintaining the animal colony. The work was carried out during the tenure of a postgraduate studentship from the Science Research Council.

\section{REFERENCES}

Austin, C.R. (1957) Oestrus and ovulation in the field vole (Microtus agrestis). F. Endocr. 15, iv. BREED, W.G. (1967) Ovulation in the genus Microtus. Nature, Lond. 214, 826.

BRUCE, H.M. (1970) Pheromones. Br. med. Bull. 10, 10-13.

Milligan, S.R. (1974) Social environment and ovulation in the vole, Microtus agrestis. F. Reprod. Fert. $41,35-47$.

Milligan, S.R. (1975) Mating, ovulation and corpus luteum function in the vole, Microtus agrestis. 7. Reprod. Fert. 42, 35-44.

WEIR, B.J. (1973) The rôle of the male in the evocation of oestrus in the cuis, Galea musteloides (Rodentia: Hystricomorpha). F. Reprod. Fert., Suppl. 19, 421-432. 